\title{
STUDI SISTEM KOMUNIKASI NIRKABEL UNTUK PENSINYALAN KERETA CEPAT INDONESIA
}

\author{
Khoirul Anwar, Ikhfan Ammar Rangkuti, Muhammad Hendra Maulana Sambas, \\ dan Abdul Khamid Ridwanuddin \\ Center for Advanced Wireless Technologies (AdWiTech), \\ Fakultas Teknik Elektro, Telkom University, \\ Jl. Telekomunikasi No. 1, Terusan Buah Batu, Bandung, 40257 Indonesia \\ Email: anwarkhoirul@telkomuniversity.ac.id, (ikhfanammar, hendrasambas, \\ abduridwanuddin)@student.telkomuniversity.ac.id
}

\begin{abstract}
Abstrak
Perkembangan teknologi sistem komunikasi yang sangat cepat berdampak kepada perkembangan sistem pensinyalan kereta cepat di seluruh dunia, termasuk Indonesia. Beragamnya sistem pensinyalan kereta cepat dunia sampai saat ini membuat Indonesia harus menentukan dengan cermat teknologi mana yang paling sesuai dengan berbagai aspek terkait perkeretaapian Indonesia. Makalah ini menyampaikan analisis dan hasil evaluasi performansi teknologi pensinyalan kereta cepat untuk membantu berbagai pihak dalam menentukan teknologi terbaik bagi Indonesia. Makalah ini melakukan evaluasi pada tiga teknologi komunikasi nirkabel untuk kereta cepat yaitu global system for mobile communication railway (GSM-R), terrestrial trunked radio - railway (TETRA), dan long-term evolution - railway (LTE-R) di dunia terkait dengan data teknis, kelebihan, kekurangan, potensi interferensi, dan keandalan teknologi terhadap kecepatan kereta. Beberapa referensi yang dirujuk dalam makalah ini berasal dari buku railway, paper, jurnal, hasil studi International Telecommunication Union (ITU), International Union of Railways (UIC), dan Asia Pacific Wireless Group (AWG). Seluruh hasil numerik didapatkan melalui simulasi komputer menggunakan parameter kondisi alam Indonesia. Hasil jurnal ini diharapkan dapat menjadi salah satu referensi dalam pemilihan teknologi dan implementasinya untuk layanan kereta cepat Indonesia di masa kini dan masa depan.
\end{abstract}

Kata Kunci: Wireless communication, GSM-R, TETRA, LTE-R, railway, interferensi.

\begin{abstract}
The development of wireless communications technologies has driven the rapid development of signaling system for high speed train, including Indonesia. Several technologies developed for high speed train makes Indonesia should carefully oberseve the best technology suited to the Indonesia natural environment. This paper performs analysis and evaluation on the wireless communication technologies used for signaling of high speed train. Some references are taken from books, journals, study of International Telecommunication Union (ITU), International Union of Railways (UIC), and Asia Pacific Wireless Group (AWG). This paper evaluates three wireless communication technology, i.e., global system for cellular-railroad communications (GSM-R), terrestrial trunked radio-railway (TETRA), and long term evolution-railway (LTE-R) in terms of technical data, advantages/disadvantages, potential interference, and effect of speed changes to the reliability. The results are expected to be one of the references for implementation of high speed train services in Indonesia.
\end{abstract}

Key Words: Wireless communication, GSM-R, TETRA, LTE-R, railway, interference.

\section{Pendahuluan}

Perkembangan teknologi yang sangat cepat pada sistem komunikasi telah memberikan dampak besar pada perkembangan sistem lain seperti sistem komunikasi pensinyalan kereta api di seluruh dunia. Sistem komunikasi pada kereta api pertama kali digunakan oleh
Great Westren Railway (GWR) yang merupakan perusahan perkeretaapian di Inggris pada tahun 1838. Pada tahun 1856, GWR menggunakan teknologi telegraf, yang disebut juga dengan "indispensable companion of railways", untuk melakukan pensinyalan antara kereta dengan stasiun[1]. Pada awalnya kereta api menggunakan hand signals, bendera, semaphore, telegraf, dan lampu 
posisi untuk melakukan pensinyalan. Hal tersebut bertahan hingga teknologi komunikasi mengalami perkembangan besar dengan hadirnya wireless radio dan lampu posisi dengan warna [2]. Hadirnya dua teknologi tersebut membantu sistem komunikasi kereta api, memungkinkan pertukaran informasi yang lebih baik antara kereta dengan stasiun serta mendukung pelayanan yang lebih lengkap.

Saat ini sistem komunikasi untuk pensinyalan kereta api semakin berkembang dengan hadirnya teknologi jaringan digital menggunakan kabel dan nirkabel. Sistem komunikasi ini juga digunakan pada sistem pensinyalan kereta cepat yang terus berkembang di seluruh dunia hingga saat ini.

Sistem komunikasi pada kereta cepat harus memiliki tingkat keandalan yang baik dengan beberapa fitur khusus yang ditujukan untuk kereta seperti yang dijelaskan pada [3]. Terdapat tiga sistem komunikasi yang saat ini digunakan di seluruh dunia yaitu global system for mobile communication - railway (GSM-R), terrestrial trunked radio - railway (TETRA) dan long term evolution railway (LTE-R). Teknologi GSM-R dan TETRA saat ini sudah banyak digunakan di seluruh dunia untuk model kereta yang berbeda-beda. Namun, penggunaan LTE-R saat ini masih pada tahap percobaan.

Beragamnya sistem komunikasi untuk pensinyalan kereta cepat di dunia sampai saat ini membuat Indonesia harus menentukan dengan cermat teknologi mana yang paling sesuai dengan kondisi alam Indonesia. Makalah ini menyampaikan analisis dan hasil evaluasi performansi teknologi pensinyalan kereta cepat, sehingga membantu berbagai pihak dalam menentukan teknologi terbaik bagi Indonesia.

\section{Model Sistem}

Makalah ini memaparkan studi tentang sistem komunikasi nirkabel yang digunakan untuk pensinyalan kereta cepat di Indonesia. Sistem komunikasi tersebut digunakan untuk membantu pensinyalan kereta agar dapat beroperasi dengan baik. Saat ini terdapat dua framework sistem perkeretaan yang digunakan di seluruh dunia yaitu European train control system (ETCS) dan China train control system (CTCS).

ETCS merupakan sistem kontrol kereta modern yang dikembangkan untuk negara-negara Eropa oleh beberapa pihak yang melakukan kerjasama internasional dan melibatkan instansi perkeretaapian dan industri, operasional serta para ahli command, control and signaling (CCS) dan juga berfungsi sebagai sistem pengawasan untuk kereta cepat berbasis transmisi dari trackside ke kereta [4]. Framework ini mendukung peningkatan keselamatan dan kinerja sistem dibandingkan dengan sistem yang ada sebelumnya [5].

Sama halnya dengan ETCS, CTCS adalah sistem pengawasan untuk kereta cepat yang pada dasarnya merupakan adopsi dari ETCS. Namun, karena alasan perkembangan sejarah dan teknis serta adanya lebih dari enam jenis sistem persinyalan kereta yang diterapkan di Eropa yang tidak dapat dioperasikan pada kereta cepat China, maka konsep CTCS diajukan pada tahun 2002 untuk kereta api China oleh Kementerian Kereta Api dan dikembangkan untuk kereta cepat China [6].

Kedua framework tersebut mendukung penggunaan tiga sistem pensinyalan kereta cepat yaitu global system for mobile communication - railway (GSM-R), terrestrial trunked radio - railway (TETRA) dan long term evolution - railway (LTE-R). Sistem GSM-R pada dasarnya merupakan sistem GSM dengan fungsionalitas perkeretaapian tertentu, salah satunya penggunaan teknik modulasi yang berbeda dengan GSM. GSM-R menggunakan teknik modulasi Gaussian minimum shift keying (GMSK) [7] yang sinyalnya dinyatakan dengan

$$
\begin{aligned}
S(t) & =\frac{1}{2}\left[\operatorname{erf}\left\{R_{a}\right\}+\operatorname{erf}\left\{R_{b}\right\}\right] \\
R_{a} & =-\sqrt{\frac{2}{\ln 2} \pi B_{3 d B}(t-a)} \\
R_{b} & =\sqrt{\frac{2}{\ln 2} \pi B_{3 d B}(t+a)}
\end{aligned}
$$

dengan $B_{3 d B}$ merupakan bandwidth 3-dB [8]. GSM-R biasanya diimplementasikan menggunakan base station (BS) khusus yang dibangun dekat dengan rel. Kendala terbesar GSM-R saat ini adalah perangkat GSM-R yang tidak tersedia untuk kedepannya di seluruh dunia sebagaimana hasil dari rapat Asia Pasific Wireless Group (AWG) [9].

TETRA merupakan penggabungan dari layanan tradisional Public Mobile Radio dan transmisi data kedalam satu sistem komunikasi yang dirancang berdasarkan metode Frequency Division Multiple Access (FDMA) dan Time Division Multiple Access (TDMA). Berdasarkan standar yang dikeluarkan European Telecommunication Standard Institute (ETSI), TETRA menggunakan $\pi / 4$-shifted differential quaternary phase shift keying ( $\pi / 4$-DQPSK) sebagai teknik modulasinya [10]. Simbol yang dimodulasi dengan teknik $\pi / 4-D Q P S K$ dinyatakan dengan

$$
\begin{aligned}
S(K) & =S(K-1) \exp (j D \phi(K)) \\
S(0) & =1
\end{aligned}
$$

dengan $S(K)$ merupakan simbol hasil modulasi dan $S(0)$ merupakan simbol hasil modulasi sebelum simbol hasil modulasi pertama dan dapat dijadikan sebagai referensi fasa.

Sedangkan pada sistem LTE-R, modulasi yang digunakan adalah quadrature phase-shift keying (QPSK). 


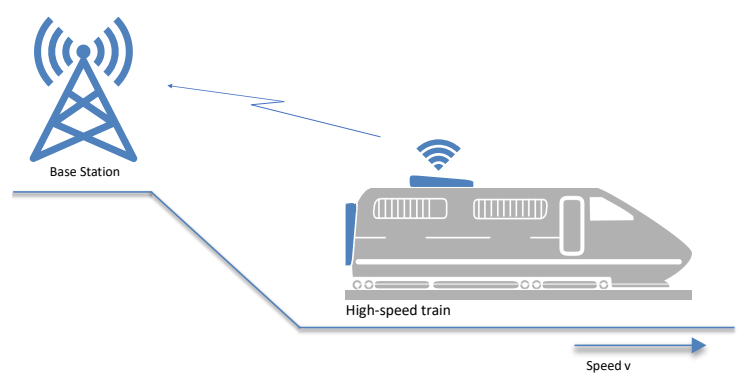

Gambar 1. Model sistem komunikasi untuk kereta cepat.

Teknik modulasi QPSK dapat dinyatakan dengan

$$
s(t)=\frac{1}{\sqrt{2}} d_{I}(t) \cos \left(2 \pi f_{c} t\right)+\frac{1}{\sqrt{2}} d_{Q}(t) \sin \left(2 \pi f_{c} t\right),
$$

dengan kanal yang menggunakan $\cos \left(2 \pi f_{c} t\right)$ sebagai sinyal carrier biasa disebut dengan inphase channel atau Ich, dan kanal yang menggunakan $\sin \left(2 \pi f_{c} t\right)$ disebut dengan quadrature-phase channel [8]. Sistem LTE-R juga dilengkapi dengan penggunaan orthogonal frequency division multiplexing (OFDM) seperti yang digunakan pada sistem LTE seluler [7]. Pada simulasi yang dilakukan, makalah ini menggunakan sistem OFDM sesuai dengan penelitian yang telah dilakukan pada [11].

Ketiga sistem komunikasi yang digunakan pada pensinyalan kereta cepat ini diuji coba menggunakan simulasi komputer dengan berbagai skenario untuk mendapatkan performansi dari kinerja sistem. Makalah ini juga mengasumsikan kondisi base station untuk kereta cepat di sepanjang jalur kereta dalam keadaan available seperti yang terdapat pada Gambar 1 .

Pada simulasi yang dilakukan, makalah ini mengasumsikan penggunaan 2 kanal berbeda yaitu kanal narrowband pada simulasi GSM-R dan TETRA, dan kanal broadband pada simulasi LTE-R. Pada simulasi, makalah ini tidak melakukan simulasi channel model yang sesuai dengan kondisi asli. Makalah ini menggunakan Rayleigh fading sebagai channel model pada kanal narrowband untuk simulasi sistem komunikasi GSM-R dan TETRA. Sedangkan pada simulasi sistem komunikasi LTE-R, pada kanal broadband, makalah ini melakukan asumsi multipath fading dengan nilai multipath delay profile $h=\left[\begin{array}{llll}1 & 0.7 & 0.3 & 0.5\end{array}\right]$. Simulasi yang dilakukan juga dipengaruhi oleh efek Doppler yang dinyatakan dengan

$$
f_{D}=\frac{v * 1000}{60 * 60 * \lambda}=\frac{v * 1000 * f}{60 * 60 * c},
$$

dengan $c$ adalah kecepatan cahaya dengan nilai $=3 \times 10^{8} \mathrm{~m} / \mathrm{s}, v$ adalah kecepatan dalam $\mathrm{km} / \mathrm{jam}$, dan $f$ adalah frekuensi kerja dalam $\mathrm{Hz}$.

Simulasi 3 sistem komunikasi GSM-R, TETRA, dan LTE-R dilakukan dalam 4 kondisi berbeda yaitu, kondisi ketika kereta cepat mengalami perubahan kecepatan, kondisi saat blocklength yang dikirim oleh pengirim berbeda-beda, kondisi pada frekuensi yang berbeda, dan kondisi saat sistem komunikasi kereta cepat terkena interferensi dengan daya interferensi yang berbeda-beda. Keempat kondisi tersebut dipilih karena faktor-faktor tersebut mempengaruhi Quality of Service (QoS) pada sistem komunikasi pensinyalan kereta cepat. Seluruh hasil simulasi pada makalah ini ditunjukkan dalam grafik bit error rate (BER).

\section{Model Kanal}

Makalah ini mengasumsikan 2 model kanal sesuai dengan sistem komunikasi yang digunakan yaitu Narrowband dan Broadband.

\subsection{Kanal Narrowband}

Sistem komunikasi pada kanal narrowband dapat diartikan sebagai sistem komunikasi yang menggunakan bandwidth frekuensi tidak lebih dari bandwidth koherennya [12]. Suatu sistem komunikasi dikatakan menggunakan kanal narrowband saat hanya ada satu sinyal yang diterima oleh receiver. Sistem komunikasi dengan kanal narrowband banyak digunakan untuk komunikasi yang membutuhkan coverage yang jauh, power yang terbatas, dan komunikasi yang reliable. Hal tersebut disebabkan oleh beberapa hal seperti kanal narrowband memiliki noise bandwidth yang rendah, tingkat sensitivitas yang lebih baik dari kanal lainnya, dan coverage yang lebih jauh [13].

Pada sistem komunikasi yang digunakan untuk pensinyalan kereta cepat, kanal narrowband digunakan oleh teknologi GSM-R dan TETRA dengan bandwidth masing-masing adalah $0.2 \mathrm{MHz}$ dan $25 \mathrm{KHz}$. Makalah ini menggunakan nilai bandwidth tersebut pada simulasi yang dilakukan.

\subsection{Broadband}

Broadband channel adalah saluran dengan bandwidth transmisi yang melebihi bandwidth koherensinya. Broadband Channel Model digunakan untuk layanan yang membutuhkan data rate tinggi [13]. Kekurangan yang dimiliki kanal broadband adalah daya pancar yang dihasilkan relatif kecil, sehingga luas area cakupannya pun menjadi lebih sempit dibandingkan dengan kanal narrowband. Dalam pensinyalan kereta cepat, broadband channel model digunakan dan dipakai oleh teknologi LTE-R karena menggunakan bandwidth sebesar $20 \mathrm{MHz}$ dalam operasi kerjanya. 


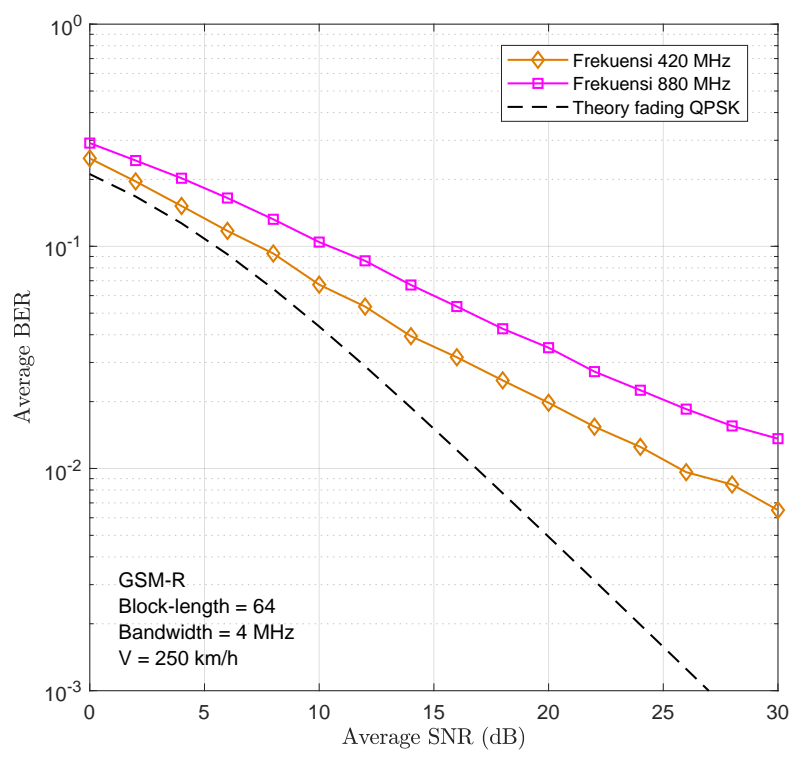

\section{Gambar 2. Performansi sistem komunikasi GSM-R pada dua frekuensi berbeda.}

\section{Evaluasi Performansi}

Makalah ini melakukan evaluasi performansi terhadap sistem komunikasi untuk pensinyalan kereta cepat. Evaluasi performansi yang dilakukan berdasarkan 4 kondisi berbeda.

\subsection{Efek Penggunaan Frekuensi}

Salah satu permasalahan penggunaan sistem komunikasi untuk pensinyalan kereta cepat yang akan dibangun di Indonesia adalah frekuensi kerja. Makalah ini melakukan analisis penggunaan 3 sistem komunikasi yang dapat digunakan untuk pensinyalan kereta cepat pada dua frekuensi kerja berbeda yaitu pada frekuensi $420 \mathrm{MHz}$ dan $880 \mathrm{MHz}$. Kedua frekuensi tersebut dipilih karena berpotensi digunakan pada sistem komunikasi untuk pensinyalan kereta cepat.

Pada simulasi ini, nilai blocklength, bandwidth, dan kecepatan diasumsikan tetap. Performansi sistem komunikasi GSM-R pada dua frekuensi berbeda ditunjukkan pada Gambar 2. Pada frekuensi $420 \mathrm{MHz}$, hasil simulasi sistem komunikasi GSM-R mendapatkan nilai rata-rata BER sebesar $10^{-2}$ pada rata-rata SNR lebih besar dari $25 \mathrm{~dB}$. Sedangkan pada frekuensi $880 \mathrm{MHz}$, hasil simulasi sistem komunikasi GSM-R mendapatkan nilai rata-rata BER di atas $10^{-2}$ pada rata-rata SNR $25 \mathrm{~dB}$.

Performansi sistem komunikasi TETRA pada dua frekuensi berbeda ditunjukkan pada Gambar 3. Pada frekuensi $420 \mathrm{MHz}$, hasil simulasi sistem komunikasi TETRA mendapatkan nilai rata-rata BER sebesar $10^{-3}$

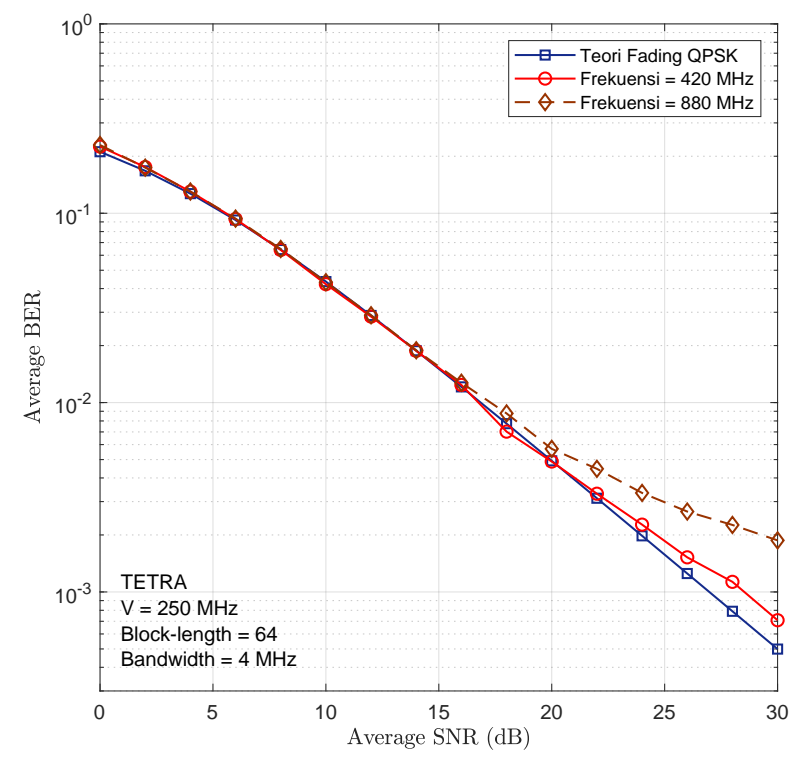

\section{Gambar 3. Performansi sistem komunikasi TETRA} pada dua frekuensi berbeda.

pada rata-rata SNR $27 \mathrm{~dB}$. Sedangkan pada frekuensi $880 \mathrm{MHz}$, hasil simulasi sistem komunikasi TETRA mendapatkan nilai rata-rata BER di atas $10^{-3}$ pada rata-rata SNR $29 \mathrm{~dB}$.

Gambar 4 menunjukkan performansi sistem komunikasi LTE-R pada dua frekuensi berbeda. Pada frekuensi $420 \mathrm{MHz}$, hasil simulasi sistem komunikasi LTE-R mendapatkan nilai rata-rata BER sebesar $10^{-3}$ pada rata-rata SNR $25 \mathrm{~dB}$. Sedangkan pada frekuensi $880 \mathrm{MHz}$, hasil simulasi sistem komunikasi LTE-R mendapatkan nilai rata-rata BER di atas $10^{-3}$ pada rata-rata SNR $30 \mathrm{~dB}$.

\subsection{Efek Perubahan Kecepatan}

Kereta cepat Indonesia rencananya akan memiliki kecepetan maksimal 350 km/jam [14]. Kecepatan tersebut tentunya memiliki pengaruh terhadap sistem komunikasi yang digunakan pada kereta. Makalah ini melakukan simulasi performansi dari tiga sistem komunikasi berbeda pada kecepatan yang berbeda-beda.

Gambar 5 menunjukkan performansi sistem komunikasi GSM-R pada kecepatan 0, 120, 160, 250, 300, dan $350 \mathrm{~km} / \mathrm{jam}$. Berdasarkan Gambar 5, dapat dilihat bahwa semakin tinggi kecepatan kereta maka performansi dari sistem akan semakin menurun. Hal tersebut ditunjukkan perbedaan nilai rata-rata BER pada kondisi saat kereta diam $(v=0)$ dan saat kereta bergerak. Saat kondisi kereta diam, dihasilkan nilai rata-rata BER sebesar $0.9 \times 10^{-3}$ pada SNR lebih besar dari $25 \mathrm{~dB}$. Sedangkan pada saat kondisi kereta bergerak $(v>0)$ rata-rata BER 


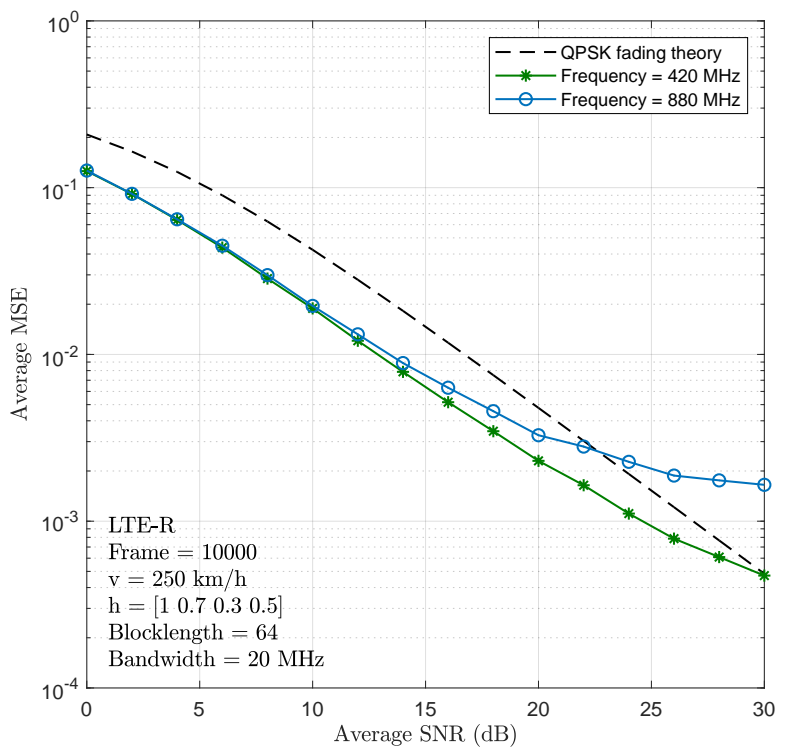

Gambar 4. Performansi sistem komunikasi LTE-R pada dua frekuensi berbeda.

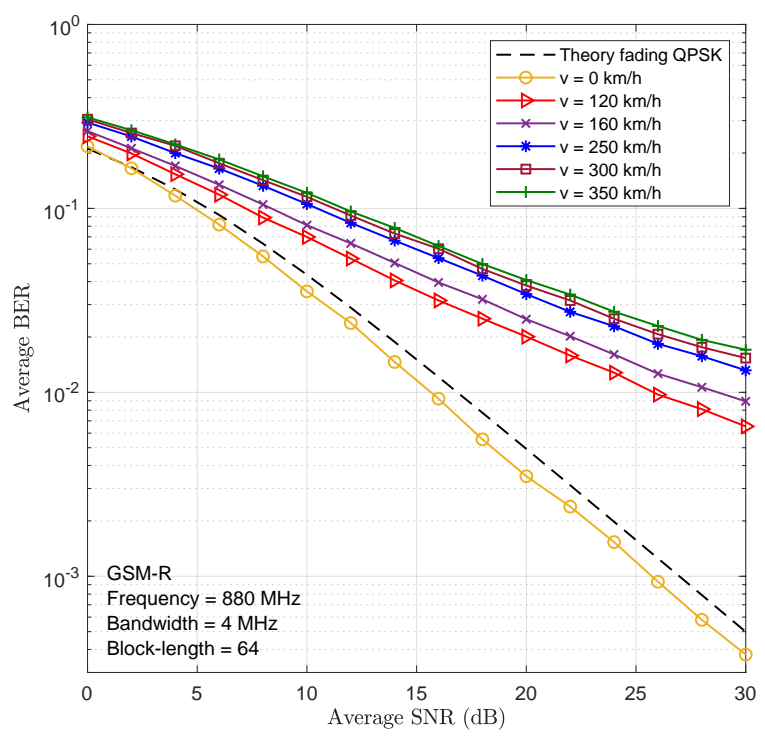

Gambar 5. Performansi sistem komunikasi GSM-R terhadap perubahan kecepatan.

bernilai kurang dari $10^{-2}$ pada rata-rata SNR lebih besar dari $25 \mathrm{~dB}$.

Pada Gambar 6, ditunjukkan performansi dari sistem komunikasi TETRA pada kecepetan yang berbeda-beda yaitu $0,200,250,300$, dan $350 \mathrm{~km} / \mathrm{jam}$. Berdasarkan Gambar 6, perubahan kecepatan yang terjadi pada kereta

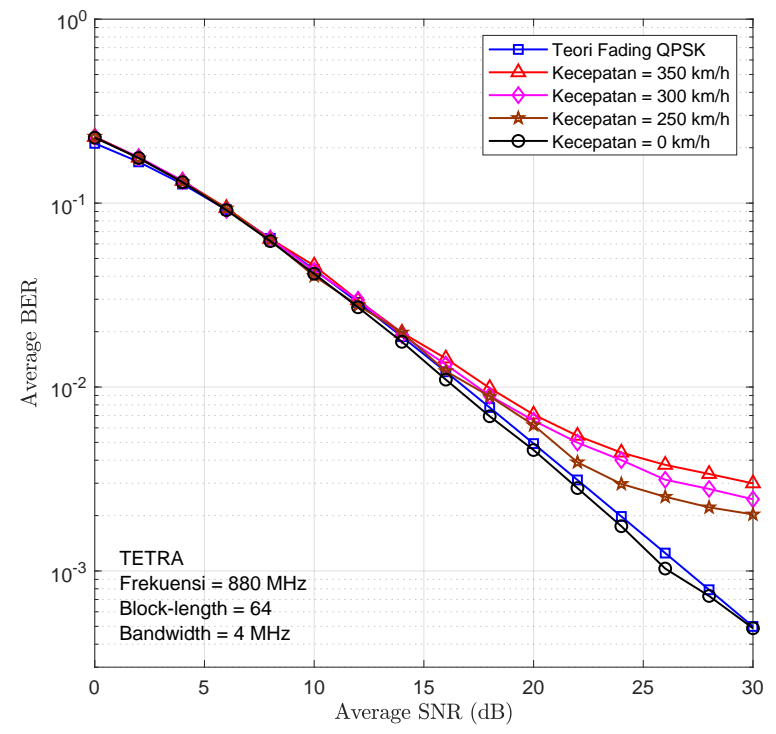

\section{Gambar 6. Performansi sistem komunikasi TETRA} terhadap perubahan kecepatan.

juga menyebabkan perubahan performansi pada sistem komunikasi TETRA sama halnya dengan sistem komunikasi GSM-R. Namun, Sistem komunikasi TETRA dapat mempertahankan performansinya tetap baik dengan nilai rata-rata BER di bawah $10^{-2}$ pada SNR lebih basar dari $25 \mathrm{~dB}$ pada saat kereta bergerak $(v>0)$. Hal tersebut menunjukkan bahwa sistem komunikasi TETRA lebih baik dari sistem komunikasi GSM-R saat terjadi perubahan kecepatan pada kereta.

Peningkatan performansi terjadi pada sistem komunikasi LTE-R yang dapat dilihat pada Gambar 7 yang dievaluasi pada kecepatan berbeda-beda yaitu 0, 120, 160, 250, 300, dan $350 \mathrm{~km} / \mathrm{jam}$. Pada saat kondisi kereta bergerak $(v>0)$, performansi sistem komunikasi LTE-R juga mengalami penurunan. Namun, sistem komunikasi LTE-R dapat mempertahankan performansinya dengan nilai rata-rata BER di bawah $10^{-2}$ pada SNR lebih dari $20 \mathrm{~dB}$. Nilai tersebut tentunya lebih baik dari sistem komunikasi TETRA yang mendapatkan nilai rata-rata BER di bawah $10^{-2}$ pada SNR lebih dari $25 \mathrm{~dB}$.

\subsection{Efek Perubahan Daya Interferensi}

Interferensi dari sistem komunikasi lain sangat merugikan bagi sistem komunikasi untuk pensinyalan kereta cepat. Hal tersebut dapat terjadi karena penggunaan frekuensi yang dekat dengan frekuensi sistem komunikasi lain. Sehingga pada makalah ini dilakukan analisis sistem komunikasi untuk pensinyalan kereta cepat pada kondisi saat adanya interferensi dari sistem komunikasi lain.

Hasil simulasi sistem komunikasi GSM-R pada 


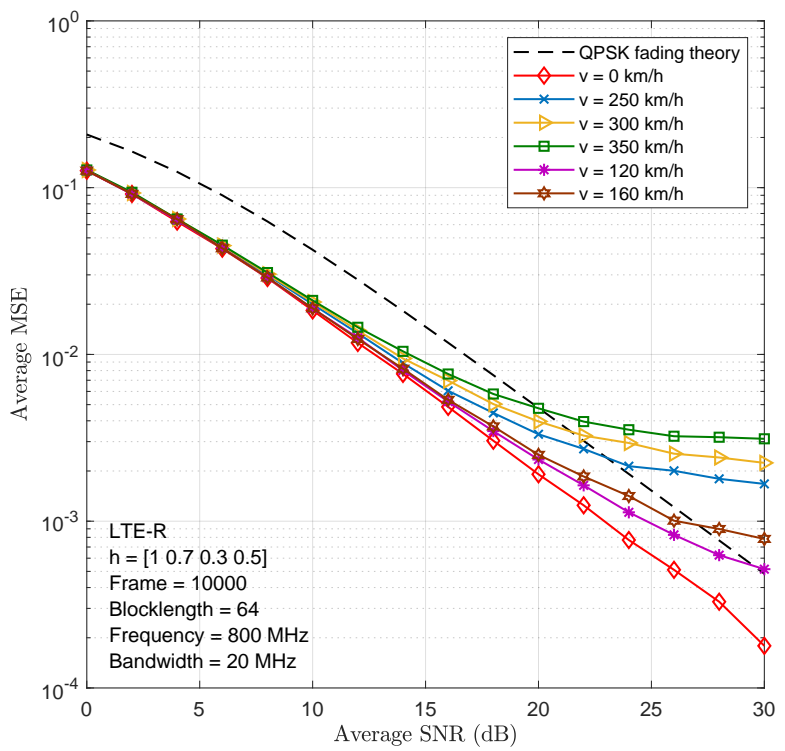

Gambar 7. Performansi sistem komunikasi LTE-R terhadap perubahan kecepatan

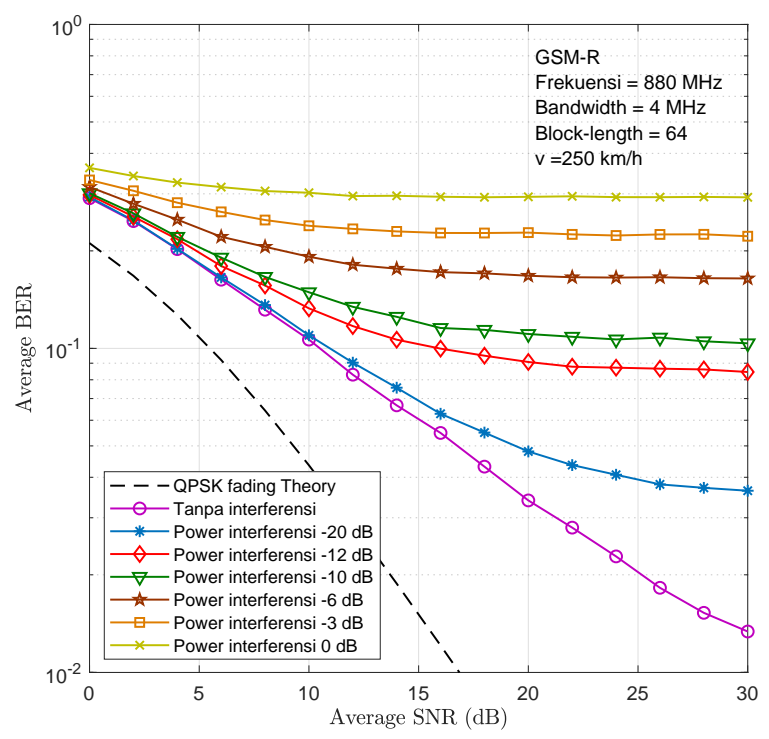

Gambar 8. Performansi sistem komunikasi GSM-R terhadap perubahan power interference

kondisi sistem komunikasi terdampak interferensi dari sistem komunikasi lain terlihat pada Gambar 8. Pada simulasi yang dilakukan, frekuensi kerja pada $880 \mathrm{MHz}$, bandwidth sebesar $4 \mathrm{MHz}$, blocklength sepanjang 64 block, dan kecepatan (v) pada $250 \mathrm{~km} / \mathrm{jam}$, diasumsikan tetap. Pada saat sistem komunikasi GSM-R tidak terkena

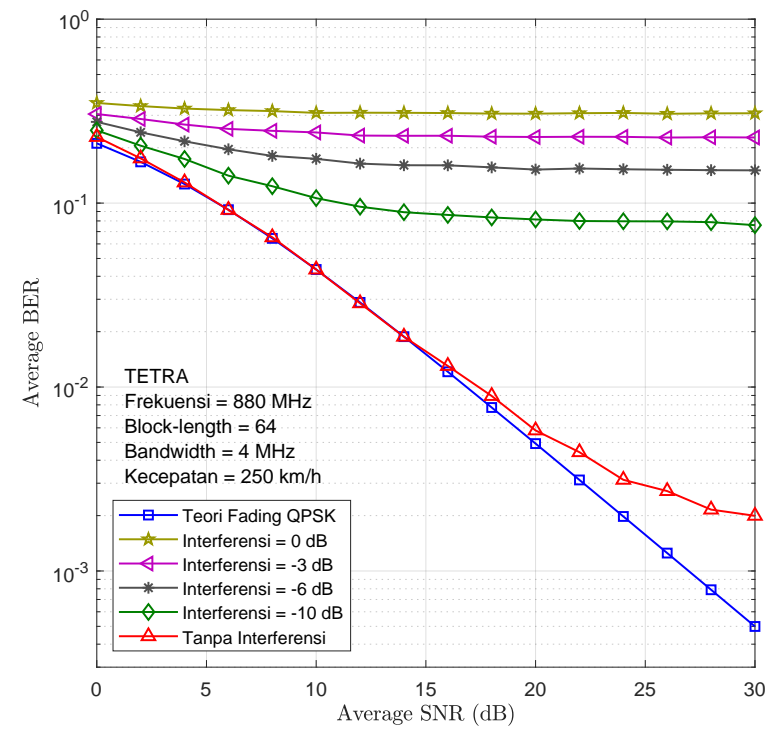

\section{Gambar 9. Performansi sistem komunikasi TETRA} terhadap perubahan power interference

interferensi dari sistem komunikasi lain, sistem komunikasi GSM-R mendapatkan nilai rata-rata BER sebesar $0.9 \times 10^{-1}$ pada rata-rata SNR $25 \mathrm{~dB}$. Namun, saat terkena interferensi dari sistem komunikasi lain, performansi sistem komunikasi GSM-R menjadi turun. Gambar 8 memperlihatkan bahwa saat daya interferensi sebesar -10 dB, sistem komunikasi GSM-R mendapatkan nilai rata-rata BER di atas $10^{-1}$ pada rata-rata SNR $30 \mathrm{~dB}$.

Makalah ini juga melakukan simulasi pada sistem komunikasi TETRA pada kondisi terkena interferensi dari sistem komunikasi lain. Gambar 9 menunjukkan performansi dari sistem komunikasi TETRA saat terkena interferensi. Sama halnya dengan sistem komunikasi GSM-R, sistem komunikasi TETRA mengalami penurunan performa yang signifikan saat terkena interferensi. Pada Gambar 9, saat daya interferensi sebesar -10 dB, sistem komunikasi TETRA mendapatkan nilai rata-rata BER sekitar $0.3 \times 10^{-1}$ pada rata-rata SNR $30 \mathrm{~dB}$. Penurunan performansi sistem komunikasi TETRA ini terjadi kemungkinan besar disebabkan karena penggunaan deteksi differential pada modulasi $\pi / 4-D Q P S K$.

Makalah ini juga melakukan simulasi pada sistem komunikasi LTE-R saat terkena interferensi. Hasil simulasi tersebut ditunjukkan pada Gambar 10. Pada Gambar 10 terlihat bahwa LTE-R memiliki ketahanan yang lebih baik daripada teknologi GSM-R maupun TETRA saat terkena interferensi. Sistem komunikasi LTE-R mendapatkan nilai rata-rata BER di bawah $10^{-1}$ pada SNR lebih dari $10 \mathrm{~dB}$ walaupun terkena interferensi 


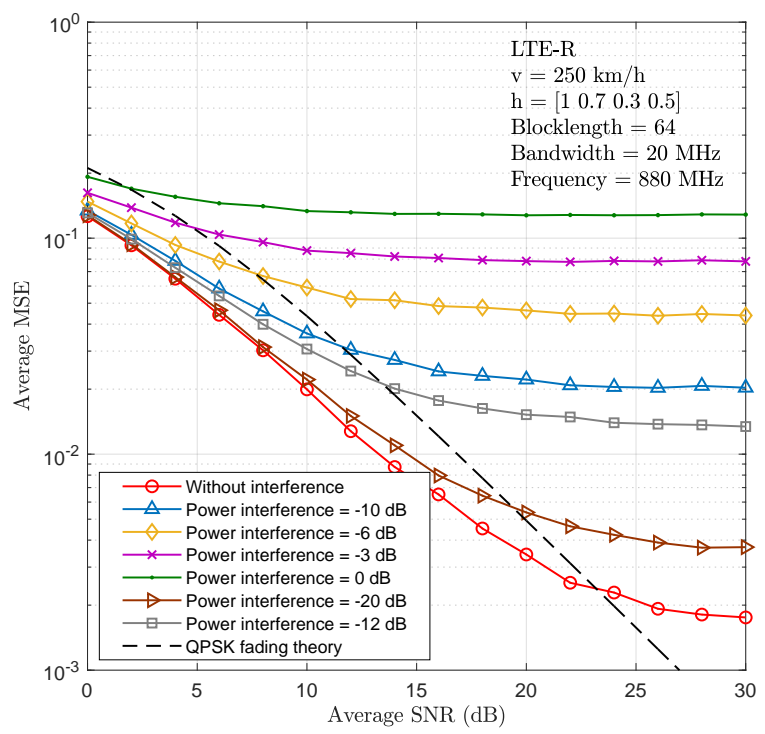

Gambar 10. Performansi sistem komunikasi LTE-R terhadap perubahan power interference

dengan daya $-3 \mathrm{~dB}$ dari sistem komunikasi lainnya.

\subsection{Efek Perubahan Blocklength}

Salah satu yang mempengaruhi performansi kinerja sistem komunikasi adalah banyaknya informasi yang dikirim. Makalah ini melakukan simulasi pada sistem komunikasi untuk pensinyalan kereta cepat pada kondisi terjadinya perubahan blocklength informasi yang dikirim.

Pada sistem komunikasi GSM-R, hasil simulasi dapat dilihat pada Gambar 11. Pada simulasi yang dilakukan, nilai frekuensi, bandwidth, dan kecepatan diasumsikan tetap. Perubahan pada blocklength mengakibatkan performansi dari sistem komunikasi GSM-R juga mengalami perubahan. Gambar 11 memperlihatkan saat blocklength berjumlah 64, nilai rata-rata BER dapat mencapai $0.9 \times 10^{-1}$ pada rata-rata SNR 25 dB. Ketika terjadi penambahan jumlah blocklength (jumlah blocklength menjadi 256), performansi sistem komunikasi GSM-R mengalami penurunan dengan nilai rata-rata BER sekitar $0.7 \times 10^{-1}$ pada rata-rata SNR $30 \mathrm{~dB}$.

Pada sistem komunikasi TETRA, hasil simulasi dapat dilihat pada Gambar 12. Pada simulasi yang dilakukan, nilai frekuensi, bandwidth, dan kecepatan diasumsikan tetap sama seperti pada simulasi sistem komunikasi GSM-R. Perubahan pada blocklength mengakibatkan performansi dari sistem komunikasi TETRA juga mengalami perubahan. Gambar 12 memperlihatkan bahwa pada saat blocklength berjumlah 64 , nilai rata-rata BER dapat mencapai $0.8 \times 10^{-2}$ pada

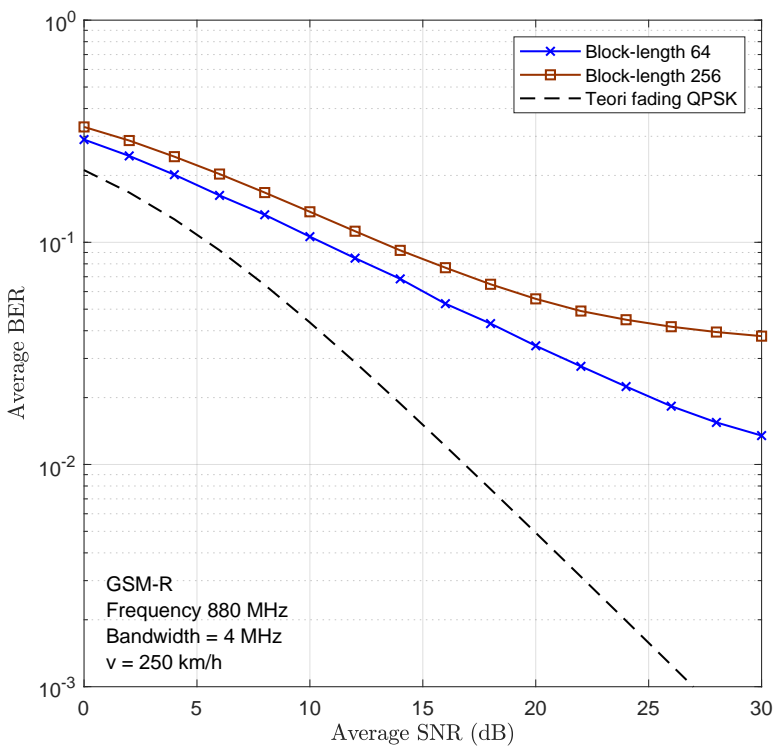

Gambar 11. Performansi sistem komunikasi GSM-R terhadap perubahan blocklength

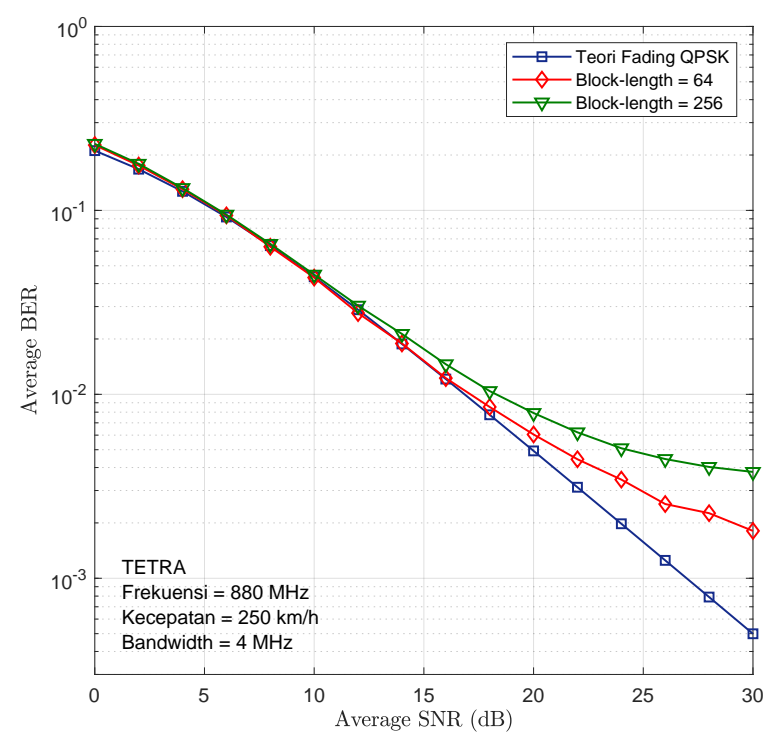

Gambar 12. Performansi sistem komunikasi TETRA terhadap perubahan blocklength

rata-rata SNR $25 \mathrm{~dB}$. Ketika terjadi penambahan jumlah blocklength (jumlah blocklength menjadi 256), performansi sistem komunikasi TETRA mengalami penurunan dengan nilai rata-rata BER sekitar $0.59 \times 10^{-2}$ pada rata-rata SNR $25 \mathrm{~dB}$.

Hasil simulasi LTE-R dapat dilihat pada Gambar 13. 


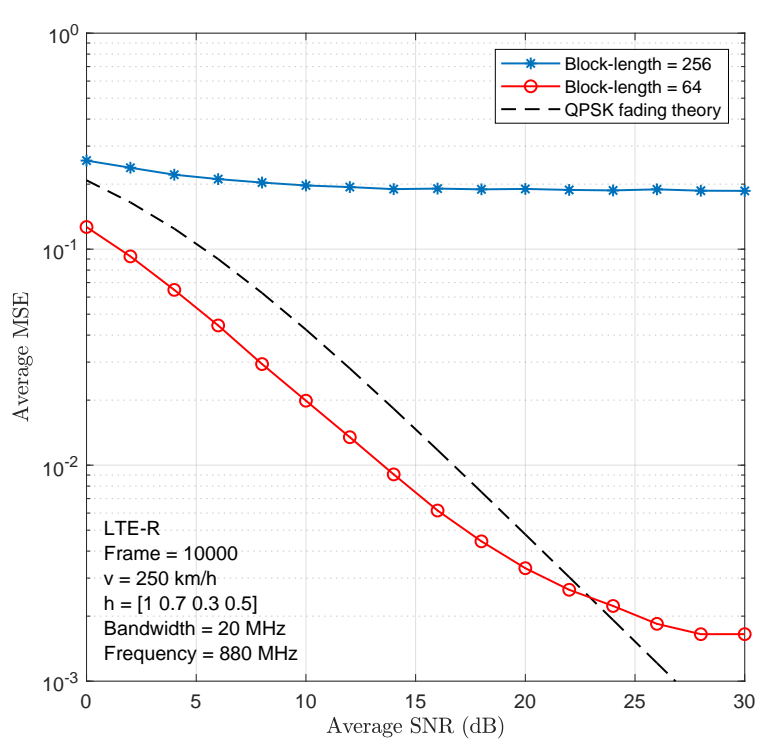

\section{Gambar 13. Performansi sistem komunikasi LTE-R} terhadap perubahan blocklength

Pada simulasi yang dilakukan, nilai frekuensi, bandwidth, dan kecepatan diasumsikan tetap sama seperti pada simulasi sistem komunikasi GSM-R dan TETRA. Perubahan pada blocklength mengakibatkan performansi dari sistem komunikasi LTE-R juga mengalami perubahan. Pada Gambar 13 dapat dilihat saat blocklength berjumlah 64, nilai rata-rata BER dapat mencapai $0.9 \times 10^{-2}$ pada rata-rata SNR $25 \mathrm{~dB}$. Ketika terjadi penambahan jumlah blocklength (jumlah blocklength menjadi 256), performansi sistem komunikasi LTE-R mengalami penurunan yang cukup signifikan dengan nilai rata-rata BER di atas $10^{-1}$. Hal tersebut menjadikan sistem komunikasi LTE-R sebagai sistem komunikasi yang paling rentan dari sistem komunikasi GSM-R dan TETRA saat terjadi perubahan blocklegth data yang dikirim.

\section{Kesimpulan}

Makalah ini telah melakukan studi komunikasi nirkabel untuk pensinyalan kereta cepat dengan teknologi GSM-R, TETRA, dan LTE-R. Ketiga teknologi telah dianalisis dan dievaluasi secara numerik menggunakan simulasi komputer berbasis kanal dan parameter alam Indonesia. Hasil studi menunjukkan bahwa teknologi GSM-R, TETRA, dan LTE-R memiliki kelebihan yang berbeda-beda dari sisi keandalan dan ketahanan terhadap beberapa hal dalam pengoperasian kereta cepat, terutama dalam aspek efek interferensi dan kecepatan kereta. Makalah ini menemukan bahwa teknologi GSM-R cukup tahan terhadap perubahan kecepatan, tetapi sensitif terhadap interferensi yang terjadi. Teknologi TETRA tahan terhadap perubahan kecepatan, tetapi juga sangat sensitif terhadap adanya interferensi sehingga kinerja menjadi turun. LTE-R kuat terhadap semua aspek dan mempunyai kelebihan diversitas sehingga menghasilkan kinerja terbaik di antara ketiga teknologi tersebut.

\section{Referensi}

[1] A. Sniady, "Communication Technologies Support to Railway Infrastructure and Operations," May 2015.

[2] G. Theeg, E. Anders, and S. Vlasenko, Railway Signalling \& Interlocking: International Compendium. Eurailpress, 2009. [Online]. Available: https://books.google.co.id/books?id=YvrSAAACAAJ

[3] UIC, "General Definition of Highspeed," 2015, https: //www.uic.org (Diakses pada 7 May 2018).

[4] M. Sango, C. Gransart, and L. Duchien, "Safety Component-Based Approach And its Application to ERTMS/ETCS On-board Train Control System," in TRA2014 Transport Research Arena, Paris, France, April 2014.

[5] P. D. Cicco, "ETCS Implementation Handbook," France, Tech. Rep., 2003.

[6] J. Wang and Z. Lin, "Research on Intelligent Control Strategy used in CTCS-3 Train Control System," Service Operations, Logistics, and Informatics (SOLI) IEEE 2011, 2011.

[7] R. He, B. Ai, G. Wang, K. Guan, Z. Zhong, A. F. Molisch, C. Briso-Rodriguez, and C. P. Oestges, "High-Speed Railway Communications: From GSMR to LTE-R," IEEE Vehicular Technology Magazine, vol. 11, no. 3, pp. 49-58, Sep. 2016.

[8] H. Harada and R. Prasad, Simulation and Software Radio for Mobile Communications. Norwood, MA, USA: Artech House, Inc., 2002.

[9] AWG-22/OUT-17, "APT Report on System Description, Technologies and Implementation of Railway Radiocommunication System between Train and Trackside (RSTT)," The 22nd Meeting of the APT Wireless Group (AWG-22), Busan, Republic of Korea, Tech. Rep., September 2017.

[10] European Telecommunication Standard Institute (ETSI), "Terrestrial Trunked Radio (TETRA); Voice plus Data $(\mathrm{V}+\mathrm{D})$; Part 2: Air Interface (AI)," 03 2001.

[11] E. Christy, R. P. Astuti, and K. Anwar, "Telkom University 5G Channel Models Under Foliage 
Effect and their Performance Evaluations," in 2018 International Conference on ICT for Rural Development (IC-ICTRuDev), Oct 2018, pp. 29-34.

[12] F. P. Fontan, P. M. Espineira, X. S. Shen, and Y. Pan, Modeling the Wireless Propagation Channel, 2008.

[13] Evander Christy and Khoirul Anwar and Rina Pudji Astuti, 5G Telkom University Channel Model Under
Foliage Effects, August 2018.

[14] F. B. Adhitia. (2018, May) Beroperasi Maret 2021, Kecepatan Kereta Cepat Jakarta-Bandung Tembus $350 \mathrm{Km} / \mathrm{Jam}$. [Online]. Available: \url\{https: //www.idntimes.com/news/indonesia/fitangadhitia/beroperasi-maret-2021-kecepatan-keretacepat-jakarta-bandung-tembus-350-kmjam-1/full 